\title{
Cost of training programs and willingness to pay for training: An application of break-even analysis in Uganda
}

\author{
Nicholas Mugumya \\ Juliana K. Nyombi \\ Michael Matsiko \\ Rick Homan \\ Harriet Birungi \\ Population Council
}

See next page for additional authors

Follow this and additional works at: https://knowledgecommons.popcouncil.org/departments_sbsr-rh

Part of the Demography, Population, and Ecology Commons, International Public Health Commons, and the Public Health Education and Promotion Commons How does access to this work benefit you? Let us know!

\section{Recommended Citation}

Mugumya, Nicholas, Juliana K. Nyombi, Michael Matsiko, Rick Homan, Harriet Birungi, and Nzoya Munguti. 2006. "Cost of training programs and willingness to pay for training: An application of breakeven analysis in Uganda," FRONTIERS Final Report. Washington, DC: Population Council. 
Authors

Nicholas Mugumya, Juliana K. Nyombi, Michael Matsiko, Rick Homan, Harriet Birungi, and Nzoya Munguti 


\title{
Cost of Training Programs and Willingness to Pay for Training: An Application of Break-Even Analysis in Uganda
}

\author{
Nicholas Mugumya, Juliana Nyombi, Michael Matsiko \\ The AIDS Support Organization (TASO) \\ Kampala, Uganda
}

\author{
Rick Homan \\ Family Health International \\ Harriet Birungi, Nzoya Munguti \\ Population Council
}

June 2006

This study was funded by the U.S. AGENCY FOR INTERNATIONAL DEVELOPMENT (USAID) under the terms of Cooperative Agreement Number HRN-A-00-98-00012-00 and Population Council Subagreement A104.45A. The opinions expressed herein are those of the authors and do not necessarily reflect the views of USAID. 


\section{ACKNOWLEDGEMENTS}

The authors would like to acknowledge the support received from different individuals and institutions during designing and implementing the study as well finalizing this report. We are grateful to the FRONTIERS Program of the Population Council for providing technical support without which this study could not have been possible. We also gratefully acknowledge the United States Agency for International Development (USAID) Office of Health, Nutrition, and Population, Research, Technology and Utilization Division for their financial support of this project.

We would like to express our appreciation for the generous support received from Dr. Alex Coutinho, the Chief Executive of TASO and members of the TASO Board. The TASO staff working in the finance department and the training center offered invaluable support during data collection.

Our appreciation also goes to our team of research assistants: Asiimwe Immaculate, Tashobya Milton, Kyomuhangi Justice, Mwongyera Justus, Herbert Ssegayi and Allan Etonu for their devotion during data collection and management.

Finally, we would like to thank all other individuals and institutions not listed here who agreed to participate in this study.

The findings, interpretations, views and conclusions in this report are entirely those of the authors. Comments and questions on this report, its contents and suggestions for improvements are always welcome.

Nicholas Mugumya

TASO Headquarters

P.O. Box, 10444,

Kampala

Tel: 041-532580

Fax: 041541288

Email: MugumyaN@tasouganda.org 


\section{TABLE OF CONTENTS}

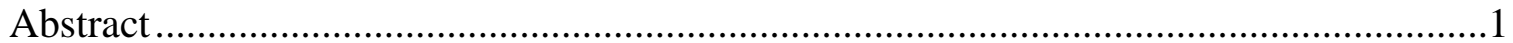

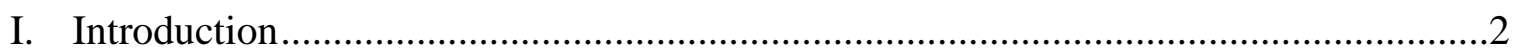

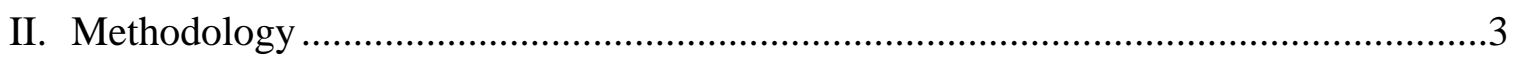

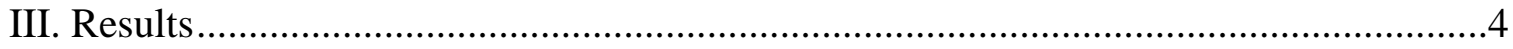

A. Costs of Courses and Break-Even Points...........................................................4

B. Potential Adjustments to Courses ..........................................................................

C. Willingness To Pay (WTP) For TASO Courses ................................................8

D. Re-Analysis of Financial Sustainability of Training Center................................9

IV. Conclusions .........................................................11

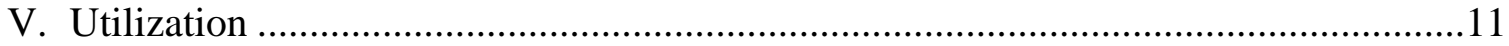

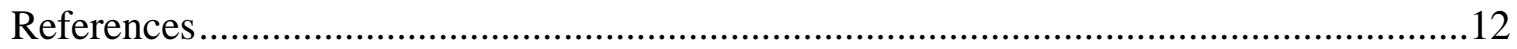

Annex 1: TASO - Description of Training Programs Offered By the Training Centre..13

Annex 2: Information Requirements, Data Sources and Measurements ........................15

Annex 3: Willingness to Pay for TASO HIV/AIDS Courses: Questionnaire for Current and Potential Clients (Individuals) .................................................16

Annex 4: Willingness to Pay for TASO HIV/AIDS Courses: Questionnaire for Current and Potential Clients (Institutions) ................................................20

Annex 5: Recommendations for increasing sustainability for specific courses ...............24 


\begin{abstract}
Background: The AIDS Support Organization (TASO) provides care and support to persons living with HIV/AIDS in Uganda. The organization also has developed a large number of training courses related to AIDS care and counseling that are offered to local and regional organizations. TASO is dependent on donors for 95 percent of its budget and wished to develop alternative funding sources. The training centre was seen as a potential revenue center. To explore alternatives for increasing the sustainability of the training center, a team from TASO attended a one-week workshop on financial sustainability and developed an operations research study to determine ways in which the training center could increase its revenues and reduce costs.
\end{abstract}

Objective: The purpose of the OR study was to determine the break-even points for the courses offered by the training center and estimate prices and numbers of participants necessary to ensure the profitable operation of the center.

Methodology: The study applied the technique of break-even analysis to identify charges for the training modules and the enrollment needed to earn positive net revenues for eleven courses. Subsequently, a willingness to pay survey was conducted among TASO training clients to assess the potential for changing the course fees.

Results: The break-even analysis enabled TASO to identify three threats to the financial sustainability of their training programs: insufficient fees, excessive costs, and inefficient course size. The willingness to pay results allowed TASO to systematically update their charges for specific training modules. Recommended changes in courses would increase cost recovery in the short term from the current level of approximately 50 percent to approximately 60 percent.

Conclusions: With updated fees as well as changes to the structure of some modules, TASO is positioned to reduce their dependency on donors and strengthen their financial base. This study also demonstrated that, with minimal technical support, an NGO was able to undertake a detailed analysis of the costs of individual programs, and use management tools like break-even analysis and willingness to pay surveys to identify programmatic changes that enhance their financial sustainability. 


\section{INTRODUCTION}

The AIDS Support Organization (TASO) was founded in 1987 to contribute to the process of restoring hope and improving the quality of life of persons and communities affected by HIV. Since 1987, TASO has served over 140,000 people with HIV/AIDS as well as provided training and indirect support to thousands more. The organization was legally incorporated as an NGO in 1991 with the backing of the AIDS Control Programme, the official government AIDS prevention organization. TASO has 10 operational branches in Mbale, Tororo, Jinja, Kampala, Entebbe, Masaka, Gulu, Mbarara, Rukungiri and Soroti as well as a collaborative hospital project in Arua. The services offered at each TASO center include medical care, counseling, social support and community training. TASO offers national and international courses at its training center in Kampala. Today, TASO is the largest indigenous NGO providing HIV/AIDS services in Uganda.

TASO's strategic plan (2003-2007) highlights the organization's failure to raise substantial local resources to co-finance its budget. The overwhelming majority of its budget (95 percent) is financed through international donations. Thus, profound concerns are being raised about program sustainability should donor support be reduced. The TASO mid-term review (2000) and the strategic plan noted that the training center has the potential to evolve into a more efficient income generating and training institution for East and Central Africa. This is evident in the increasing training requests from districts and recently (2002) from the Regional AIDS Training Network (RATN) and ACTIONAID. While the demand for training has been steadily increasing, little income has been realized. The problem has been associated with the inability of the organization to determine appropriate charges for its courses that will enable the training center to break-even.

To respond to the above concerns, a team from TASO attended a one-week training workshop on financial sustainability and developed a small operations research project to examine the cost of their training programs and the revenues collected from these programs. The overall goal of this study was to improve the financial sustainability of the TASO training center.

The specific study objectives were to determine: the break-even point for the courses offered by the training center; appropriate charges for the training services; and to explore the potential for cost containment within the training center activities. Upon establishing the actual cost of the training programs, a follow-up survey on willingness to pay was conducted with a view to evaluate the feasibility of changing current fees to levels that would enable the centre to recover the cost of training. 


\section{METHODOLOGY}

Cost and price information was gathered on the eleven most frequently offered TASO courses. Each course was analyzed using a break-even technique to establish the course fees and number of students needed for the course to be financially sustainable. Break-even analysis is a technique that allows the researcher to determine the level of output (in this case number of trainees) at which total costs would be equal to total revenues. Prior to the break-even point (where costs exceed revenues), losses are experienced. After the break-even point (where revenues exceed costs), profits are obtained. The analysis allowed TASO to estimate prices and the number of trainees needed to convert the training center from a cost liability to a revenue asset. The break-even point is calculated as follows:

$$
\mathrm{T}=\mathrm{TFC} \div(\mathrm{FEE}-\mathrm{AVC})
$$

Where: $\mathrm{T}$ is the number of trainees required to break-even, TFC = the total fixed costs for the course (see Annex 2 for an example of fixed costs), $\mathrm{FEE}=$ the per trainee course fee, and AVC $=$ the average variable cost per student for the course (see Annex 2 for an example of variable costs)

The expression (FEE - AVC) is referred to as the Contribution Margin.

The training center's eleven most frequently offered courses were included in this study.

CRS01: AIDS Care Orientation Workshop

CRS02: Introduction to HIV Counseling

CRS03: HIV/AIDS Counseling Course (Modular)

CRS04: HIV/AIDS Counseling Course (Block)

CRS05: HIV/AIDS Counselor Supervisor's Course

CRS06: HIV/AIDS Counselor Refresher Course

CRS08: HIV/AIDS Community Care Course (TOT)

CRS11: Refresher Course for Community Trainers

CRS13: Child Counseling Course

CRS14: Youth Peer Counseling Course

CRS15: Client Peer Counseling Course

A description of each course including duration, class size, and current fees is presented in Annex 1.

Interviews and record reviews were used to gather information on resources used in the courses. The resources included labor, supplies/materials, equipment, venue costs, buildings, travel costs, accommodation and allowances for the participants. A complete listing of cost elements with data sources for expenditures can be found in Annex 2.

Information gathered on resource inputs was used to establish the full cost of providing training and to determine the break-even point for each course. The unit of analysis was the number of participants per course. Therefore costs were defined as fixed or variable with respect to the number of students in the course. Examples of fixed costs include the time of the trainers, equipment used, support staff time required per course, and other infrastructure. Examples of 
variable costs include meals and transport for trainees, supplies, and any per diems for trainers and participants. The analysis estimated the variable, fixed, and total cost of each course. The ratio of total revenues to total cost gives the cost recovery percentage for the course, which is a rough indication of how far the course is from being financially sustainable.

In situations where the contribution margin is negative (course fee less than average variable cost), the course cannot generate positive net revenues because every additional participant implies an additional loss. To improve the sustainability of these courses, either variable costs must be reduced and/or revenues increased.

In cases with a positive contribution margin, the break-even level of production (class size) may exceed what is feasible given the logistics of teaching and the size of the training center. In this situation the strategies of reducing variable cost, reducing fixed costs, and/or increasing course fees should be explored.

The cost data were also examined for potential reductions in course length and/or size (if positive contribution margin is obtainable). Changing the course length can reduce both the fixed and variable costs, while increasing the course size will reduce the average cost per student, and raise the cost recovery percentage since total revenues will increase faster than total costs.

A willingness to pay (WTP) survey assessed potential increases in course fees. If survey respondents would accept course fee increases, this would yield greater cost recovery and a lower break-even point (due to larger contribution margin per student). A total of 453 interviews were conducted with actual and potential local participants including both individuals and organizations. We focused on the course fees paid by local participants since in all cases except one (CRS05, Counselor Supervisor's Course) the fee charged to international participants was sufficient to offset the cost per student.

\section{RESULTS}

\section{A. Costs of courses and Break-Even Points:}

Results of the cost analysis with current break-even points and cost recovery percentages for the training services offered by TASO are presented in Table 1. The unit of currency is the Uganda Shilling. In February 2006, the exchange rate was approximately 1,815 shillings to one United States Dollar. Comparing the computed cost per student (column 6) and current charges per course participant (column 7) indicates that the cost per student of providing the courses exceeds the fees charged per course participant except for courses CRS 06 (Counselor Refresher Course) and CRS 11 (Clients Peer Counseling Course). This is an indication that the training centre is unable to recover costs from the training services due to under-pricing. For all courses, TASO is only able to recoup about $52 \%$ of the training costs incurred (column 11).

The contribution margin per student for five courses (CRS 01, 04, 05, 14, and15) was negative, an indication that the current charges per participant are unable to cover variable costs. In this case, adding more students to the course will increase the loss as costs will increase faster than 
revenues, and therefore no figure is given for the break-even point (column 10). It is worth noting that the cost recovery percentage for these courses is usually below 33\%, a level that limits the financial sustainability of the training center.

For courses with positive contribution margins, column 10 shows the number of students required for each course to break-even. Except for courses CRS 06 and CRS 11, the required course size is likely to be greater than the number of students that could be handled at any one time due to logistical and pedagogical constraints. For CRS 06 and CRS 11, the current class size is sufficient for the courses to generate positive net revenues. 
Table 1: Cost Analysis of TASO Courses with Current Break-even Points and Current Cost Recovery Percentage

\begin{tabular}{|c|c|c|c|c|c|c|c|c|c|c|}
\hline $\begin{array}{c}(1) \\
\text { Course ID }\end{array}$ & $\begin{array}{c}(2) \\
\text { Total Variable } \\
\text { Cost per } \\
\text { Course } \\
\text { (USh.) }\end{array}$ & $\begin{array}{c}(3) \\
\text { Total Non- } \\
\text { Variable Costs } \\
\text { per Course } \\
\text { (USh.) }\end{array}$ & $\begin{array}{l}\text { (4) } \\
\text { Overall Cost per } \\
\text { Course (USh.) }\end{array}$ & $\begin{array}{c}\text { (5) } \\
\text { \# of } \\
\text { Students } \\
\text { per Course }\end{array}$ & $\begin{array}{c}(6) \\
\text { Computed } \\
\text { Cost per } \\
\text { Student } \\
\text { (USh.) }\end{array}$ & $\begin{array}{c}\text { (7) } \\
\text { Current } \\
\text { Charges per } \\
\text { Student (USh.) }\end{array}$ & $\begin{array}{c}\text { (8) } \\
\text { Expected } \\
\text { Revenue per } \\
\text { Course } \\
\text { (USh.) }\end{array}$ & $\begin{array}{c}\text { (9) } \\
\text { Contribution } \\
\text { Margin per } \\
\text { Student } \\
\text { (USh.) }^{1}\end{array}$ & \begin{tabular}{|c|}
$(10)$ \\
Break-even \\
Point \\
(\# Students per \\
Course) $^{2}$ \\
\end{tabular} & $\begin{array}{c}(11) \\
\text { Cost } \\
\text { Recovery } \\
(\%)^{3}\end{array}$ \\
\hline CRS 01 & $12,031,500$ & $5,108,182$ & $17,139,682$ & 30 & 571,323 & 260,000 & $7,800,000$ & $-141,050$ & N/a & 45.5 \\
\hline CRS 02 & $1,180,000$ & $9,904,402$ & $11,084,402$ & 20 & 554,220 & 260,000 & $5,200,000$ & 201,000 & 49 & 46.9 \\
\hline \begin{tabular}{|l|} 
CRS 03 \\
\end{tabular} & $2,721,000$ & $23,741,384$ & $26,462,384$ & 20 & $1,323,119$ & 560,000 & $11,200,000$ & 423,950 & 56 & 42.3 \\
\hline CRS 04 & $16,341,000$ & $26,375,448$ & $42,716,448$ & 20 & $2,135,822$ & 700,000 & $14,000,000$ & $-117,050$ & N/a & 32.8 \\
\hline CRS 05 & $20,700,000$ & $29,648,866$ & $50,348,866$ & 15 & $3,356,591$ & 360,000 & $5,400,000$ & $-1,020,000$ & N/a & 10.7 \\
\hline CRS 06 & $2,940,000$ & $4,756,952$ & $7,696,952$ & 15 & 513,130 & 560,000 & $8,400,000$ & 364,000 & 13 & 109.1 \\
\hline \begin{tabular}{|l|} 
CRS 08 \\
\end{tabular} & $18,411,000$ & $21,691,799$ & $40,102,799$ & 20 & $2,005,140$ & $1,525,000^{4}$ & $30,500,000$ & 604,450 & 36 & 76.1 \\
\hline CRS 11 & $3,720,000$ & $5,041,291$ & $8,761,291$ & 20 & 438,065 & 560,000 & $11,200,000$ & 374,000 & 13 & 127.8 \\
\hline CRS 13 & $40,688,750$ & $39,676,860$ & $80,365,610$ & 25 & $3,214,624$ & $2,532,000^{4}$ & $63,300,000$ & 904,450 & 44 & 78.8 \\
\hline CRS 14 & $9,300,000$ & $9,832,785$ & $19,132,785$ & 20 & 956,639 & 260,000 & $5,200,000$ & $-205,000$ & N/a & 27.2 \\
\hline CRS 15 & $9,300,000$ & $9,832,785$ & $19,132,785$ & 20 & 956,639 & 260,000 & $5,200,000$ & $-205,000$ & N/a & 27.2 \\
\hline
\end{tabular}

Note: 1,815 USh. $=\$ 1$

\footnotetext{
1 Computed as Current Charge per Student less Variable Cost per Student

2 Computed as Total Non Variable Costs $\div$ Contribution Margin per Student

If greater than zero, this indicates the number of students required per course to generate sufficient revenue to offset the cost of offering the course.

If contribution margin is negative, the course cannot break-even under the current cost and revenue structure and a break-even point is not computed.

${ }^{3}$ Computed as Expected Revenue per Course $\div$ Overall Cost per Course, the average across the 11 courses equals $51.8 \%$

${ }^{4}$ Weighted average of international and local students course fees
} 
With an average cost recovery of 52\%, the training center cannot break-even under the current cost and revenue structure. The break-even point analysis has enabled TASO to identify three threats to the financial sustainability of their training programs: trainings with insufficient fees, trainings with excessive costs, and trainings of inefficient size. In the next section, potential changes to the structure of courses and their impact on cost recovery will be explored.

\section{$\underline{\text { B. Potential Adjustments to Courses }}$}

The data in Table 1 display the following patterns:

- A number of courses have costs in excess of 10.0 million USh. per course week (CRS 01, CRS 04, CRS 05, CRS 08, and CRS 13). Strategies to reduce the total costs of these courses should be explored.

- The ratio of the negative contribution margin to the current course fee for some courses (CRS 01, CRS 05, CRS 14, and CRS 15) makes it unlikely that an increase in the course fee could be sufficient to generate a positive contribution margin. For example, the fee for CRS 01 would need to increase by $54.3 \%$ before the contribution margin would be positive. Therefore strategies to reduce the variable costs of these courses become important.

- For some courses, variable costs account for more than $40 \%$ of total costs (CRS 01, CRS 05, CRS 08, CRS 11, CRS 13, CRS 14 and CRS 15). In these cases, strategies to reduce the variable costs of these courses should be explored.

Four possible modifications might be considered to reduce costs and improve revenues:

- Elimination of participant per diem payments which account for a large proportion of the variable costs of some courses (CRS 01, CRS 05, CRS 08, and CRS 13);

- Reducing the length of the course (CRS 02, CRS 03, CRS 04, CRS 14, and CRS 15) in order to reduce both the fixed and variable costs of the course;

- Replacement of outside consultants (CRS 05 and CRS 13) with TASO staff in order to reduce the fixed (labor) and some variable costs (lodging and per diems for consultants) for the courses; and

- Changing the course size for courses with positive contribution margins and structures that may be conducive to larger cohorts (CRS 06 and CRS 15)

These strategies were modeled to provide information to TASO on the relative potential benefits of each of the above modifications. Table 2 below examines the potential impact and notes the change in the course cost recovery percentage associated with each potential modification. 
Table 2: Impact of Potential Cost Containment Strategies by Course

\begin{tabular}{|c|c|c|}
\hline Course ID & Potential Impact & Change in Cost Recovery \% \\
\hline \multicolumn{3}{|c|}{ Eliminate Participant Per Diems } \\
\hline CRS 01 & Reduce variable costs by 9.9 million USh. & Increase from $45.5 \%$ to $107.7 \%$ \\
\hline CRS 05 & Reduce variable costs by 19.5 million USh & Increase from $10.7 \%$ to $18.5 \%$ \\
\hline CRS 08 & Reduce variable costs by 16.8 million USh & Increase from $78.5 \%$ to $130.9 \%$ \\
\hline CRS 13 & Reduce variable costs by 40.4 million USh & Increase from $78.8 \%$ to $158.4 \%$ \\
\hline \multicolumn{3}{|c|}{ Reduce Course Length (classroom days) } \\
\hline CRS 02 & Reduce to 7 days, reduces total cost by 3.6 million USh. & Increase from $46.9 \%$ to $69.7 \%$ \\
\hline CRS 03 & Reduce to 20 days, reduces total cost by 4.8 million USh. & Increase from $42.3 \%$ to $51.7 \%$ \\
\hline CRS 04 & Reduce to 10 days, reduces total cost by 7.7 million USh. & Increase from $32.8 \%$ to $40.0 \%$ \\
\hline CRS 14 & Reduce to 5 days, reduces total cost by 8.0 million USh. & Increase from $27.2 \%$ to $46.9 \%$ \\
\hline CRS 15 & Reduce to 5 days, reduces total cost by 8.0 million USh. & Increase from $27.2 \%$ to $46.9 \%$ \\
\hline \multicolumn{3}{|c|}{ Replace Consultant } \\
\hline CRS 05 & $\begin{array}{l}\text { Total payment is } 7.9 \text { million USh. ( } 15.7 \% \text { of total cost) } \\
\text { Net savings depends on how replaced }\end{array}$ & Uncertain \\
\hline CRS 13 & $\begin{array}{l}\text { Total payment is } 4.4 \text { million USh. ( } 5.5 \% \text { of total cost) } \\
\text { Net savings depends on how replaced }\end{array}$ & Uncertain \\
\hline \multicolumn{3}{|c|}{ Increase Class Size } \\
\hline CRS 05 & Increase class size to 20 , increases revenue by $1,800,000$ USh. & Increase from $10.7 \%$ to $14.5 \%$ \\
\hline CRS 06 & $\begin{array}{l}\text { Increase participants to 20, increases variable cost by } 980,000 \\
\text { USh., Increases revenues by } 2.8 \text { million USh. }\end{array}$ & Increase from $109.1 \%$ to $129.1 \%$ \\
\hline CRS $15^{1}$ & $\begin{array}{l}\text { Increase to } 25 \text {, increases variable cost by } 1.3 \text { million USh., } \\
\text { increases revenues by } 1.3 \text { million USh. }\end{array}$ & Increase from $46.9 \%$ to $52.6 \%$ \\
\hline
\end{tabular}

${ }^{1}$ Only if the course length has been reduced to 5 days so that there is a positive contribution margin per student.

\section{Willingness To Pay (WTP) For TASO Courses}

TASO also examined the potential for increases in user fees to increase course revenues. Table 3 provides a summary of the results of the WTP analysis. When there were substantial differences in WTP by type of respondent (individual vs. institutional), then results are presented separately by type of participant (CRS 06 only). However a preference is given for a uniform fee for local participants for ease of administration and marketing. 
Table 3: WTP Analysis of TASO Courses

\begin{tabular}{|l|c|c|c|c|c|}
\hline \multicolumn{1}{|c|}{$\begin{array}{c}\text { Course } \\
\text { ID }\end{array}$} & $\begin{array}{c}\text { WTP } \\
\text { Sample } \\
\text { Size }\end{array}$ & $\begin{array}{c}\text { Current } \\
\text { Course Fee }\end{array}$ & $\begin{array}{c}\text { WTP } \\
80 \text { th } \\
\text { percentile }\end{array}$ & $\begin{array}{c}\text { Recommended } \\
\text { Course Fee }\end{array}$ & $\begin{array}{c}\text { Expected } \\
\text { Contribution Margin } \\
\text { per Student }\end{array}$ \\
\hline CRS 01 & 114 & 260,000 & 401,344 & $410,000^{3}$ & 8,950 \\
\hline CRS 02 & 83 & 260,000 & 311,035 & 310,000 & 251,000 \\
\hline CRS 03 & 149 & 560,000 & 573,652 & $560,000^{4}$ & 423,950 \\
\hline CRS 04 & 32 & 700,000 & 726,385 & 725,000 & $-92,050$ \\
\hline CRS 05 & 96 & 360,000 & 438,590 & 440,000 & $-940,000$ \\
\hline $\begin{array}{l}\text { CRS 06 } \\
\text { individuals }\end{array}$ & 35 & 560,000 & 594,935 & 600,000 & 404,000 \\
\hline $\begin{array}{l}\text { CRS 06 } \\
\text { institutions }\end{array}$ & 26 & 560,000 & 737,241 & 735,000 & 539,000 \\
\hline CRS 08 & 192 & 500,000 & 594,894 & 600,000 & 654,450 \\
\hline CRS 11 & 41 & 560,000 & 596,364 & 600,000 & 414,000 \\
\hline CRS 13 & 122 & $1,500,000$ & $1,531,104$ & $1,500,000^{4}$ & 904,450 \\
\hline CRS 14 & 169 & 260,000 & 372,916 & $435,000^{5}$ & $-30,000$ \\
\hline CRS 15 & 83 & 260,000 & 306,345 & 310,000 & $-155,000$ \\
\hline
\end{tabular}

${ }^{1}$ Course fee for local participants only

2 Imputed using linear estimate between fees directly above and below 80th percentile

3 Desire to generate a small positive contribution margin

4 Negligible increase possible

5 This corresponds to the 77.5th percentile and is selected since \% WTP is relatively constant from 375,000 USh. to 435,000 USh.

\section{Re-Analysis of Financial Sustainability of Training Programs}

Looking at Table 3, it is clear that TASO is unlikely to obtain a positive contribution margin for CRS 04, CRS 05, CRS 14 and CRS 15 through fee schedule changes alone, leading TASO to examine the potential of combining the strategies from Table 2 with the fee changes recommended in Table 3. Similarly, the replacement of an outside consultant (CRS 05) is a longer-term strategy whose financial impact needs to be considered carefully. Therefore the only combinations analyzed were shortening of CRS 14 and CRS 15 to 5 days, and increasing enrollment in CRS 06 and CRS 15. The combined impact of these changes with the fee increases is shown in Table 4.

The changes increase the average cost recovery per course from 52 to 61 percent. The reduction of per diems would also make CRS 01, CRS 08, and CRS 13 self-financing. However, CRS 04 and CRS 05 cost recovery remains quite low and they have very high total costs relative to course length. CRS 02 and CRS 03 both suffer from relatively high fixed costs. For CRS 02, perhaps the best way to sustain this course is to assure that at least half the participants are international so that they can subsidize local participants.

For CRS 03, there is little scope of attracting international participants for a 6-month course of study therefore a cross-subsidy from international participants is unlikely. TASO should examine the costs of running this course and assess whether the didactic portion of the course can be shortened. 
Table 4: Cost Analysis of TASO Courses with Revised Course Fees and Selected Course Structure Modifications

\begin{tabular}{|c|c|c|c|c|c|c|c|c|c|c|}
\hline $\begin{array}{c}(1) \\
\text { Course ID }\end{array}$ & \begin{tabular}{|c|}
$(2)$ \\
Total Variable \\
Cost per \\
Course \\
(USh.)
\end{tabular} & \begin{tabular}{|c|} 
(3) \\
Total Non-Variable \\
Costs per Course \\
(USh.)
\end{tabular} & \begin{tabular}{|c|}
$(4)$ \\
Overall Cost per \\
Course (USh.)
\end{tabular} & \begin{tabular}{|c|} 
(5) \\
\# of \\
Students \\
per Course
\end{tabular} & $\begin{array}{c}\text { (6) } \\
\text { Computed } \\
\text { Cost per } \\
\text { Student } \\
\text { (USh.) }\end{array}$ & $\begin{array}{c}(7) \\
\text { Revised } \\
\text { Charges per } \\
\text { Student (USh.) }\end{array}$ & $\begin{array}{c}(8) \\
\text { Expected } \\
\text { Revenue per } \\
\text { Course } \\
\text { (USh.) }\end{array}$ & $\begin{array}{c}\text { (9) } \\
\text { Contribution } \\
\text { Margin per Student } \\
\text { (USh.) }^{5}\end{array}$ & \begin{tabular}{|c|}
$(10)$ \\
Break-even Point \\
(\# Students per \\
Course) ${ }^{6}$
\end{tabular} & $\begin{array}{c}\text { (11) } \\
\text { Cost } \\
\text { Recovery } \\
(\%)^{7}\end{array}$ \\
\hline \begin{tabular}{|c|} 
CRS 01 \\
\end{tabular} & $12,031,500$ & $5,108,182$ & $17,139,682$ & 30 & 571,323 & 410,000 & $12,300,000$ & 8,950 & 571 & 71.8 \\
\hline CRS 02 & $1,180,000$ & $9,904,402$ & $11,084,402$ & 20 & 554,220 & 310,000 & $6,200,000$ & 251,000 & 40 & 55.9 \\
\hline CRS 03 & $2,721,000$ & $23,741,384$ & $26,462,384$ & 20 & $1,323,119$ & 560,000 & $11,200,000$ & 423,950 & 57 & 42.3 \\
\hline \begin{tabular}{|c|} 
CRS 04 \\
\end{tabular} & $16,341,000$ & $26,375,448$ & $42,716,448$ & 20 & $2,135,822$ & 725,000 & $14,500,000$ & $-92,050$ & N/a & 33.9 \\
\hline CRS 05 & $20,700,000$ & $29,648,866$ & $50,348,866$ & 15 & $3,356,591$ & 440,000 & $6,600,000$ & $-940,000$ & N/a & 13.1 \\
\hline CRS 06 & 3,920,000 & 4,756,952 & $8,676,952$ & $20^{8}$ & 433,848 & 667,500 & $13,350,000$ & 471,500 & 11 & 153.9 \\
\hline CRS 08 & $18,411,000$ & $21,691,799$ & $40,102,799$ & 20 & $2,005,140$ & $1,575,000^{9}$ & $31,500,000$ & 654,450 & 34 & 78.5 \\
\hline CRS 11 & $3,720,000$ & $5,041,291$ & $8,761,291$ & 20 & 438,065 & 600,000 & $12,000,000$ & 414,000 & 13 & 137.0 \\
\hline CRS 13 & $40,688,750$ & $39,676,860$ & $80,365,610$ & 25 & $3,214,624$ & $2,532,000^{9}$ & $63,300,000$ & 904,450 & 44 & 78.8 \\
\hline CRS $14^{10}$ & $5,100,000$ & $5,981,932$ & $11,081,932$ & 20 & 554,097 & 435,000 & $8,700,000$ & 180,000 & 34 & 78.5 \\
\hline CRS $15^{10}$ & $6,375,000$ & $5,981,932$ & $12,356,932$ & 25 & 494,277 & 310,000 & $7,750,000$ & 55,000 & 109 & 62.7 \\
\hline
\end{tabular}

${ }^{5}$ Computed as Current Charge per Student less Variable Cost per Student

${ }^{6}$ Computed as Total Non Variable Costs $\div$ Contribution Margin per Student

If greater than zero, this indicates the number of students required per course to generate sufficient revenue to offset the cost of offering the course.

If contribution margin is negative, the course cannot break-even under the current cost and revenue structure and a break-even point is not computed.

7 Computed as Expected Revenue per Course $\div$ Overall Cost per Course, the average cost recovery \% across the 11 courses equals $61 \%$

${ }^{8}$ Increase from 15 students per course

${ }^{9}$ Weighted average of international and local students course fees

${ }^{10}$ Course length shortened to 5 class days from 10 class days 


\section{CONCLUSIONS}

Modeling training costs and the impacts of different cost control and cost recovery options improved the information available for both short and long-term decisionmaking. The study verified that the TASO Training Center recovered only a small percent of its operating costs, and demonstrated that measures could be implemented fairly rapidly that would reduce the operating deficit. These measures would not allow the training center to break-even, let alone generate profits for cross-subsidization of AIDS care programs. Consequently, TASO decided to implement some of the measures with the potential of reducing the deficit, and importantly to plan changes in the marketing of the courses that are expected to eventually convert the training program into an income-generating center.

Specifically, the study ascertained that the training center could not break-even under its current cost and revenue structure, and identified three basic threats to the financial sustainability of the program: insufficient fees, excessive costs, and courses of inefficient size. Partial, rapidly implementable solutions to these problems include raising fees, reducing variable costs such as participant per-diems, reducing course duration, increasing class sizes, and replacing relatively costly outside instructors with instructors recruited from within TASO.

The results also suggest that the proposed changes are not likely to enable the training center to become financially independent of donors in the near future. However, the center's ability to increase cost-recovery into the $60 \%$ range still represents a non-trivial improvement in financial sustainability. Aside from the immediate financial benefits to TASO, the commitment to good financial management, and the desire to become more self-sustaining demonstrated by this study should make the organization a more attractive recipient of continued donor support.

A general strategy, not analyzed in this study, but worth exploring, includes more marketing of TASO training programs to international participants. The higher fees that these participants are able and willing to pay can be used to subsidize local participants. To avoid displacing local participants with higher paying international students, TASO should consider setting limits on the ratio of international to local participants. Another strategy worth exploring would be to offer dedicated courses to institutions at a fixed fee that guarantees a net-profit that could be used to subsidize other courses.

\section{UTILIZATION}

Based upon the results of these analyses, the TASO Board, in October 2005, approved the suggested changes in course fees and began exploring ways that cost reductions could be achieved. In addition, the Committee requested that the training center begin analysis of the potential for direct marketing of dedicated training modules to local and international organizations. The Committee is also planning a market analysis of competing training organizations with respect to the content of their programs and an assessment of how TASO's fees compare for similar modules. Longer term strategies that will be explored are: changes to the curricula to shorten the training period for some courses, exploring the complementary marketing of courses, and collaboration with the Regional AIDS Training Network to attract more international participants to subsidize local participants. 


\section{REFERENCES}

Janowitz, Barbara and John H. Bratt, 1994. "Methods for Costing Family Planning Services” United Nations Population Fund and Family Health International.

Foreit, KG and JR. Foreit 2001 "Willingness to Pay for Setting Fees for Reproductive Health Products and Services. A User’s Manual.” Frontiers in Reproductive Health, Population Council and Policy Project, The Futures Group International.

TASO’s strategic plan (2003-2007)

TASO mid-term review (2000)

TASO work plans and budgets (2003-2004) 
ANNEX 1: TASO - DESCRIPTION OF TRAINING PROGRAMS OFFERED BY THE TRAINING CENTRE

\begin{tabular}{|c|c|c|c|c|c|}
\hline Course \# & Course Title & Description & $\begin{array}{l}\text { Duration \& } \\
\text { Enrollment }\end{array}$ & Local Rates & $\begin{array}{l}\text { International } \\
\text { Rates }\end{array}$ \\
\hline CRS 01 & $\begin{array}{l}\text { AIDS Care } \\
\text { Orientation } \\
\text { Workshop } \\
\text { (ACOW) }\end{array}$ & $\begin{array}{l}\text { A sensitization workshop aimed at orienting participants to help people with } \\
\text { HIV/AIDS related concerns. It addresses individual vulnerability and } \\
\text { responsibilities, facts about HIV/AIDS, positive attitudes and basic helping } \\
\text { skills among others. It is suitable for district leaders, managers, supervisors } \\
\text { and persons or institutions that wish to provide integrated HIV/AIDS work. }\end{array}$ & $\begin{array}{l}1 \text { week } \\
30 \text { students }\end{array}$ & USh. 260,000 & US\$ 600 \\
\hline CRS 02 & $\begin{array}{l}\text { Introduction } \\
\text { to HIV/AIDS } \\
\text { Counseling }\end{array}$ & $\begin{array}{l}\text { A course aimed at training a cadre of health care providers in preparing } \\
\text { clients for HIV/AIDS testing and receiving test results. It addresses basic } \\
\text { facts about HIV/AIDS, basic helping skills, pre- and post-test counseling } \\
\text { skills. It is suitable for individual working in health, testing institutions or } \\
\text { working as counseling aides. }\end{array}$ & 2 weeks & USh. 260,000 & US\$ 600 \\
\hline CRS 03 & $\begin{array}{l}\text { HIV/AIDS } \\
\text { Counseling } \\
\text { course } \\
\text { (Modular) }\end{array}$ & $\begin{array}{l}\text { This course aims at training a cadre of counselors capable of meeting the } \\
\text { information needs of clients, preparing them for HIV test and test results, as } \\
\text { well as providing the necessary psychological support for positive life style } \\
\text { with HIV/AIDS. It addresses counseling theories and evolution, counseling } \\
\text { modes, counseling techniques, ethical issues in HIV/AIDS care and code of } \\
\text { conduct for counseling practice, behavior change, among others. }\end{array}$ & $\begin{array}{l}6 \text { months } \\
25 \text { class } \\
\text { days \& } 24 \\
\text { weeks of } \\
\text { field } \\
\text { practice. } \\
20 \text { students }\end{array}$ & USh. 560,000 & N/a \\
\hline CRS 04 & $\begin{array}{l}\text { HIV/AIDS } \\
\text { Counseling } \\
\text { course } \\
\text { (Block) }\end{array}$ & $\begin{array}{l}\text { This course is designed to suit the needs of international participants who } \\
\text { find it convenient to attend full time, class-based but short time courses of } \\
\text { not more than } 4 \text { weeks. The course is run jointly with the Regional AIDS } \\
\text { Training Network (RATN). It is aimed at training a cadre of counselors } \\
\text { capable of meeting the information needs of clients, preparing them for HIV } \\
\text { test and test results, as well as providing the necessary psychological support } \\
\text { for positive life style with HIV/AIDS. It addresses counseling theories and } \\
\text { evolution, counseling modes, counseling techniques, ethical issues in } \\
\text { HIV/AIDS care and code of conduct for counseling practice, behavior } \\
\text { change, among others. }\end{array}$ & $\begin{array}{l}4 \text { weeks } \\
\text { (modular) } \\
15 \text { class } \\
\text { days and } 1 \\
\text { week of } \\
\text { field } \\
\text { practice. } \\
20 \text { students }\end{array}$ & USh. 700,000 & US\$ 2400 \\
\hline CRS 05 & $\begin{array}{l}\text { HIV/AIDS } \\
\text { Counselor } \\
\text { Supervisor's } \\
\text { Course }\end{array}$ & $\begin{array}{l}\text { A course aimed at building the capacity of program/project managers to } \\
\text { supervise HIV/AIDS counselors. It addresses counseling standards, practice, } \\
\text { support and supervision in addition to monitoring and evaluation. }\end{array}$ & 2 weeks & USh. 360,000 & US\$ 1200 \\
\hline
\end{tabular}




\begin{tabular}{|c|c|c|c|c|c|}
\hline Course \# & Course Title & Description & $\begin{array}{l}\text { Duration \& } \\
\text { Enrollment }\end{array}$ & Local Rates & $\begin{array}{l}\text { International } \\
\text { Rates }\end{array}$ \\
\hline CRS 06 & $\begin{array}{l}\text { HIV/AIDS } \\
\text { Counselor } \\
\text { Refresher } \\
\text { Course }\end{array}$ & $\begin{array}{l}\text { This is an intensive course aimed at refreshing and updating practicing } \\
\text { counselors with the latest development and approved global best practices in } \\
\text { different HIV/AIDS service provision. Participants are given updates on } \\
\text { different themes as per the current global HIV/AIDS epidemic dynamics. }\end{array}$ & $\begin{array}{l}1 \text { week } \\
15 \text { students }\end{array}$ & USh. 560,000 & \\
\hline CRS 08 & $\begin{array}{l}\text { HIV/AIDS } \\
\text { Community } \\
\text { Care Course } \\
\text { (TOT) }\end{array}$ & $\begin{array}{l}\text { This course is offered in partnership with the Regional AIDS Training } \\
\text { Network (RATN). It aims at improving the quality of care given at the } \\
\text { community level, increasing community capacity to cope with HIV/AIDS } \\
\text { and prevent further transmission of HIV. Participants learn how to supervise } \\
\text { and support community care projects, monitoring and evaluation of AIDS } \\
\text { programs, developing training activities, project planning, community } \\
\text { education, motivation and coping strategies. }\end{array}$ & $\begin{array}{l}3 \text { weeks } \\
20 \text { students }\end{array}$ & USh. 500,000 & US\$ 1500 \\
\hline CRS 11 & $\begin{array}{l}\text { Refresher } \\
\text { Course for } \\
\text { Community } \\
\text { Trainers }\end{array}$ & $\begin{array}{l}\text { An intensive course aimed at community trainers. It offers an opportunity to } \\
\text { address field-based challenges and updates participants on current trends and } \\
\text { best practices in HIV/AIDS. }\end{array}$ & $\begin{array}{l}1 \text { Week } \\
20 \text { students }\end{array}$ & Varies & Varies \\
\hline CRS 13 & $\begin{array}{l}\text { Child } \\
\text { Counseling } \\
\text { Course }\end{array}$ & $\begin{array}{l}\text { A demand driven course aimed at equipping middle levels managers and } \\
\text { TOT trainers to enhance their competences required in managing emotional } \\
\text { needs of children infected and affected by HIV/AIDS. It is an intensive, } \\
\text { highly participatory course with both class and field based hands-on } \\
\text { activities. The course addresses foundation and counseling children, foreign } \\
\text { and African theoretical perspectives to child counseling, ethical issues and } \\
\text { challenges of parenting, among others. }\end{array}$ & $\begin{array}{l}3 \text { weeks } \\
25 \text { students }\end{array}$ & $\begin{array}{l}\text { USh. } \\
1,500,000\end{array}$ & US\$ 2400 \\
\hline CRS 14 & $\begin{array}{l}\text { Peer } \\
\text { Counseling } \\
\text { Course } \\
\text { (Youth) }\end{array}$ & $\begin{array}{l}\text { This course is meant to empower youth with skills in mobilizing fellow } \\
\text { peers towards the fight against HIV/AIDS. The course focuses on } \\
\text { mobilization skills, basic counseling and helping skills. }\end{array}$ & $\begin{array}{l}2 \text { weeks } \\
20 \text { students }\end{array}$ & USh. 260,000 & Varies \\
\hline CRS 15 & $\begin{array}{l}\text { Peer } \\
\text { Counseling } \\
\text { Course } \\
\text { (Clients) }\end{array}$ & $\begin{array}{l}\text { This course targets people living with HIV/AIDS. The course focuses on } \\
\text { mobilization skills, basic counseling, public speaking/ giving out } \\
\text { testimonies, among others. }\end{array}$ & $\begin{array}{l}2 \text { weeks } \\
20 \text { students }\end{array}$ & USh. 260,000 & Varies \\
\hline
\end{tabular}




\section{ANNEX 2: INFORMATION REQUIREMENTS, DATA SOURCES AND MEASUREMENTS}

\begin{tabular}{|l|l|l|}
\hline Type of Costs & Data Source & Cost Classification 11 \\
\hline Direct Costs & & \\
\hline Trainers' Salaries \& Benefits & Payroll & Fixed \\
\hline Trainers' Preparation Time & Trainers & Fixed \\
\hline Per Diem for Trainers & Accounts Records & Fixed \\
\hline Per Diem for Trainees & Accounts Records & Variable \\
\hline Meals & Accounts Records & Variable \\
\hline Trainers' Transport & Accounts Records & Fixed \\
\hline Trainees' Transport & Accounts Records & Variable \\
\hline Venue & Accounts Records & Fixed \\
\hline Equipments & Accounts Records & Fixed \\
\hline Ceremonies & Accounts Records & Some Fixed, Some Variable \\
\hline Stationery & Accounts Records & Variable \\
\hline Certificates & Accounts Records & Variable \\
\hline Training Materials & Accounts Records & Some Fixed, Some Variable \\
\hline Support Costs & & \\
\hline Support Staff Salaries \& Benefits & Payroll & Fixed \\
\hline Support Staff Preparation Time & Support Staff & Fixed \\
\hline Other Allowances for Support Staff & Accounts Records & Fixed \\
\hline Utilities & Accounts Records & Fixed \\
\hline Capital Costs & Accounts Records & Fixed \\
\hline Management Overheads & Accounts Records \& & Fixed \\
\hline
\end{tabular}

${ }^{11}$ Distinction of fixed vs. variable is based upon consideration of whether the magnitude of the cost will likely change in response to a small change in the number of students attending the course. 


\section{ANNEX 3: WILLINGNESS TO PAY FOR TASO HIV/AIDS COURSES: QUESTIONNAIRE FOR CURRENT AND POTENTIAL CLIENTS (INDIVIDUALS)}

Section A: Informed Consent for individuals to Participate in TASO Willingness to Pay Interviews

Good morning/afternoon Madam or Sir? I am from TASO, The AIDS Support Organization. I am here to carry out a willingness to pay study. TASO is currently reviewing its fee structure for the different training courses it offers. We are seeking individual as well as organizational opinions about the fee structure in order to determine realistic fees that are acceptable.

The interview that I would like to conduct with you is confidential and nothing you say will affect your relationship with the TASO training center. I will appreciate honest opinions about the questions I am going to ask you. Your name will not appear on any of the interviews nor in any reports. Your participation is voluntary. The information obtained will be used to improve the sustainability of TASO training centers.

It will take about 30 minutes to complete the interview. Do you have any questions about the study? (If yes the interviewer should note down the questions in the space provided below)

Please feel free to contact the following persons if you have any doubts or questions about the study: Nicholas Mugumya, Michael Matsiko, and Juliana Nyombi, Tel: 25641-532580/1, 256-77-471827

Do you agree to participate in this interview now or reschedule to a later day? Yes (proceed to interview): No (thank respondent)

(As part of an ethical requirement for the conduct of research, I would like to request you to sign here as an indication of your consent)

Interviewee’s Signature Date

Interviewer's Signature as witness

Date

Thank you in advance for your cooperation

Interviewer Name: 
Section B: Demographic Data

Please choose the appropriate response and circle answer in the box provided below.

\begin{tabular}{|l|l|l|}
\hline 101 Sex & Male & 1 \\
\cline { 2 - 3 } & Female & 2 \\
\hline 102 What is your occupation? & Teacher & 1 \\
\cline { 2 - 3 } & Social worker & 2 \\
\cline { 2 - 3 } & Health worker & 3 \\
\cline { 2 - 3 } & Project officer & 4 \\
\hline & Trainer & 5 \\
\cline { 2 - 3 } & Other (specify) & 6 \\
\hline------------------------------- & \\
\hline & Government & 1 \\
\cline { 2 - 3 } & District & 2 \\
\cline { 2 - 3 } & NGO & 3 \\
\cline { 2 - 3 } & Church/Faith-based & 4 \\
& Organization & 6 \\
\cline { 2 - 3 } & Research organization & 5 \\
\cline { 2 - 3 } & Private company & 7 \\
\cline { 2 - 3 } & Other (specify) & 6 \\
\hline
\end{tabular}

At this point please hand course list card to interviewee 


\section{Section C: $\quad$ WILLINGNESS TO PAY (individuals)}

104. Would you please look at this card that lists the main courses taught by TASO, and tell me which courses you have attended (interviewer to record responses in question 104.1and follow the questions as indicated in the table below).

\begin{tabular}{|c|c|c|c|c|c|}
\hline $\begin{array}{l}\text { Course } \\
\text { No. }\end{array}$ & Type of Courses offered & $\begin{array}{l}104.1 \\
\text { Have you ever } \\
\text { attended } \\
\text { <name> } \\
\text { course? } \\
\text { Yes (GO TO } \\
\text { QS.104.2) } \\
\text { No (GO TO } \\
\text { QS. 104.4) }\end{array}$ & $\begin{array}{l}104.2 \\
\text { How much did } \\
\text { you pay for } \\
\text { <name> } \\
\text { course? } \\
\text { (In USh.) } \\
\text { 99. Not } \\
\text { applicable }\end{array}$ & $\begin{array}{l}104.3 \\
\text { Do you think the tuition fee you } \\
\text { paid for }<\text { name }>\text { course matches } \\
\text { with the training services you } \\
\text { received from TASO Training } \\
\text { center? } \\
\text { Very much } \\
\text { To some extend } \\
\text { Left a lot to be desired } \\
\text { Not at all } \\
\text { Others (specify) } \\
\text { 99. Not Applicable } \\
\text { (GO TO QS. 104.4) }\end{array}$ & $\begin{array}{l}104.4 \\
\text { Would you be } \\
\text { interested in attending } \\
\text { any other courses in } \\
\text { future? Which ones in } \\
\text { particular? } \\
\text { Yes } \\
\text { No } \\
\text { 99. Not Applicable }\end{array}$ \\
\hline CRS01 & $\begin{array}{l}\text { AIDS Orientation } \\
\text { Workshop } \\
(\text { ACOW) }\end{array}$ & & & & \\
\hline CRS02 & $\begin{array}{l}\text { Introduction to } \\
\text { HIV/AIDS } \\
\text { Counseling }\end{array}$ & & & & \\
\hline CRS03 & $\begin{array}{l}\text { HIV/AIDS } \\
\text { Counseling Course } \\
\text { (Modular) }\end{array}$ & & & & \\
\hline CRS04 & $\begin{array}{l}\text { HIV/AIDS } \\
\text { Counseling Course } \\
\text { (Block) }\end{array}$ & & & & \\
\hline CRS05 & $\begin{array}{l}\text { HIV/AIDS } \\
\text { Counselor } \\
\text { Supervisors' } \\
\text { Course } \\
\end{array}$ & & & & \\
\hline CRS06 & $\begin{array}{l}\text { Counselor } \\
\text { Refresher Course }\end{array}$ & & & & \\
\hline CRS08 & $\begin{array}{l}\text { HIV/AIDS } \\
\text { Community care } \\
\text { Course (TOT)- } \\
\text { Regional }\end{array}$ & & & & \\
\hline CRS011 & $\begin{array}{l}\text { TOT Community } \\
\text { Refresher course }\end{array}$ & & & & \\
\hline CRS013 & $\begin{array}{l}\text { Child Counseling } \\
\text { Course }\end{array}$ & & & & \\
\hline CRS014 & $\begin{array}{l}\text { Peer Counseling } \\
\text { Course (Youth) }\end{array}$ & & & & \\
\hline CRS015 & $\begin{array}{l}\text { Peer Counseling } \\
\text { Course (Clients) }\end{array}$ & & & & \\
\hline
\end{tabular}

(Note which rows are marked " 1 " for Q. 104.4 and go to question 201) 
Instruction to interviewer: The following questions only applicable to courses that an individual has expressed interest in attending Q. 104.4]

201. I now want to ask you questions about changes in fees for particular courses that you are interested in attending. Assuming your current income remains the same and that there may be other agencies/institutions offering similar training courses other than TASO. (Work across one row then go to next row)

\begin{tabular}{|c|c|c|c|c|c|c|}
\hline \multirow[t]{2}{*}{$\begin{array}{l}\text { Course } \\
\text { Number }\end{array}$} & \multirow[t]{2}{*}{ Courses } & $\begin{array}{l}201.1 \\
\text { Would you still be } \\
\text { interested in attending } \\
<\text { course }>\text { if the fee } \\
\text { increased from } \\
<\text { amount }>\text { to } \\
<\text { amount }>\text { ? }\end{array}$ & $\begin{array}{l}201.2 \\
\text { Would you still be } \\
\text { interested in attending } \\
<\text { course }>\text { if the fee } \\
\text { increased from } \\
<\text { amount }>\text { to } \\
<\text { amount }>\text { ? }\end{array}$ & $\begin{array}{l}201.3 \\
\text { What if the fees for } \\
<\text { name }>\text { course were } \\
\text { increased from } \\
<\text { amount }>\text { to } \\
<\text { amount }>\text { would you } \\
\text { still attend the course? }\end{array}$ & \multirow{2}{*}{$\begin{array}{l}201.4 \\
\text { What is the } \\
\text { highest fee you } \\
\text { would be willing } \\
\text { to pay to attend } \\
\text { <name> course? } \\
\text { (Insert Amounts } \\
\text { in USh.) }\end{array}$} & \multirow{2}{*}{$\begin{array}{l}201.5 \\
\text { What would you do if } \\
\text { TASO raised the fee for } \\
<\text { course }>\text { beyond } \\
<201.4>\text { ? } \\
\text { Go without the training } \\
\text { Find way to attend } \\
\text { TASO training } \\
\text { Seek training elsewhere } \\
\text { (please specify)* } \\
\text { 99. Not Applicable }\end{array}$} \\
\hline & & $\begin{array}{l}\text { Yes (go to } 20 \\
\text { No. (go to } 2 \\
\text { 99. Not App }\end{array}$ & $\begin{array}{l}\text { 1. Yes (go to } \\
\text { 2. No (go to } \\
\text { 99. Not Appli }\end{array}$ & $\begin{array}{l}\text { 1. Yes (go to } \\
\text { 2. No (go to } 2 \\
\text { 99. Not Appli }\end{array}$ & & \\
\hline CRS01 & AIDS Orientation Workshop (ACOW) & $\begin{array}{l}260,000 \text { to } \\
510,000\end{array}$ & $\begin{array}{l}260,000 \text { to } \\
635,000\end{array}$ & $\begin{array}{l}260,000 \text { to } \\
385,000\end{array}$ & & \\
\hline CRS02 & $\begin{array}{l}\text { Introduction to HIV/AIDS } \\
\text { Counseling }\end{array}$ & $\begin{array}{l}260,000 \text { to } \\
510,000\end{array}$ & $\begin{array}{l}260,000 \text { to } \\
635,000\end{array}$ & $\begin{array}{l}260,000 \text { to } \\
385,000\end{array}$ & $\ldots \ldots$ & \\
\hline CRS03 & $\begin{array}{l}\text { HIV/AIDS Counseling Course } \\
\text { (Modular) }\end{array}$ & $\begin{array}{l}560,000 \text { to } \\
1,060,000 \\
\end{array}$ & $\begin{array}{l}560,000 \text { to } \\
1,310,000\end{array}$ & $\begin{array}{l}560,000 \text { to } \\
810,000\end{array}$ & & \\
\hline CRS04 & $\begin{array}{l}\text { HIV/AIDS Counseling Course } \\
\text { (Block) }\end{array}$ & $\begin{array}{l}700,000 \text { to } \\
1,100,000\end{array}$ & $\begin{array}{l}700,000 \text { to } \\
1,300,000\end{array}$ & $\begin{array}{l}700,000 \text { to } \\
900,000\end{array}$ & & \\
\hline CRS05 & $\begin{array}{l}\text { HIV/AIDS Counselor } \\
\text { Supervisors’ Course }\end{array}$ & $\begin{array}{l}360,000 \text { to } \\
760,000\end{array}$ & $\begin{array}{l}360,000 \text { to } \\
960,000\end{array}$ & $\begin{array}{l}360,000 \text { to } \\
560,000\end{array}$ & & \\
\hline CRS06 & Counselor Refresher Course & $\begin{array}{l}560,000 \text { to } \\
910,000\end{array}$ & $\begin{array}{l}560,000 \text { to } \\
1,085,000\end{array}$ & $\begin{array}{l}560,000 \text { to } \\
735,000\end{array}$ & . & \\
\hline CRS08 & $\begin{array}{l}\text { HIV/AIDS Community care } \\
\text { Course (TOT)- Regional }\end{array}$ & $\begin{array}{l}500,000 \text { to } \\
1,000,000\end{array}$ & $\begin{array}{l}500,000 \text { to } \\
1,250,000\end{array}$ & $\begin{array}{l}500,000 \text { to } \\
750,000\end{array}$ & , $\ldots \ldots \ldots+\cdots \cdots$ & \\
\hline CRS011 & $\begin{array}{l}\text { TOT Community Refresher } \\
\text { Course }\end{array}$ & $\begin{array}{l}560,000 \text { to } \\
910,000\end{array}$ & $\begin{array}{l}560,000 \text { to } \\
1,085,000\end{array}$ & $\begin{array}{l}560,000 \text { to } \\
735,000\end{array}$ & & \\
\hline CRS013 & Child Counseling Course & $\begin{array}{l}1,500,000 \text { to } \\
2,000,000\end{array}$ & $\begin{array}{l}1,500,000 \text { to } \\
2,250,000\end{array}$ & $\begin{array}{l}1,500,000 \text { to } \\
1,750,000\end{array}$ & ................... & \\
\hline CRS014 & Peer Counseling Course (Youth) & $\begin{array}{l}260,000 \text { to } \\
610,000\end{array}$ & $\begin{array}{l}260,000 \text { to } \\
785,000\end{array}$ & $\begin{array}{l}260,000 \text { to } \\
435,000\end{array}$ & & \\
\hline CRS015 & Peer Counseling Course (Clients) & $\begin{array}{l}260,000 \text { to } \\
610,000\end{array}$ & $\begin{array}{l}260,000 \text { to } \\
785,000\end{array}$ & $\begin{array}{l}260,000 \text { to } \\
435,000\end{array}$ & & \\
\hline
\end{tabular}

Thank you for your cooperation 


\section{ANNEX 4: WILLINGNESS TO PAY FOR TASO HIV/AIDS COURSES: QUESTIONNAIRE FOR CURRENT AND POTENTIAL CLIENTS (INSTITUTIONS)}

Section A: Informed Consent for individuals to Participate in TASO Willingness to Pay Survey

Good morning/afternoon Madam or Sir? I am from TASO, The AIDS

Support Organization. I am here to carry out a willingness to pay study. TASO is currently reviewing its fee structure for the different training courses it offers. We are seeking individual as well as organizational opinions about the fee structure in order to determine realistic fees that are acceptable.

The interview that I would like to conduct with you is confidential and nothing you say will affect your relationship with the TASO training center. I will appreciate honest opinions about the questions I am going to ask you. Your name will not appear on any of the interviews nor in any reports. Your participation is completely voluntary. The information obtained will be used to improve the sustainability of TASO training centers.

It will take about 30 minutes to complete the interview. Do you have any questions about the study? (If yes the interviewer should note down the questions in the space provided below)

Please feel free to contact the following persons if you have any doubts or questions about the study: Nicholas Mugumya, Michael Matsiko, and Juliana Nyombi, Tel: 25641-532580/1, 256-77-471827

Do you agree to participate in this interview now or reschedule to a later day? Yes (proceed to interview): No (thank respondent)

(As part of an ethical requirement for the conduct of research, I would like to request you to sign here as an indication of your consent)

Interviewee’s Signature

Interviewer's Signature as witness

Date

Thank you in advance for your cooperation

Interviewer Name: 
Section B: Background Information

Please choose the appropriate response and indicate the number in brackets in the box provided below.

100 Name of Institution:

101 Nature of Institution:

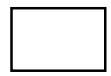

Government/Ministry/Agency

Faith-Based Organization (FBO)

Non-Governmental Organization (NGO)

International Agency

Other (specify).........................

102. Major service offered by the institution (multiple responses allowed - circle all appropriate answers)

Health Care

Counseling

Relief

Child Care

Policy Implementers

Others (specify)

At this point please hand course list card to interviewee 


\section{Section C: $\quad$ WILLINGNESS TO PAY (institutions)}

Would you please look at this card that lists the main courses taught by TASO, and tell me which courses you have sponsored your staff to attend

\begin{tabular}{|c|c|c|c|c|}
\hline $\begin{array}{l}\text { Course } \\
\text { No. }\end{array}$ & $\begin{array}{l}\text { Type of Courses offered by TASO } \\
\text { training center }\end{array}$ & $\begin{array}{l}103.1 \\
\text { Have you ever sponsored } \\
\text { your staff to attend }<\text { name }> \\
\text { course? } \\
\text { Yes } \\
\text { No }\end{array}$ & $\begin{array}{l}103.2 \\
\text { In future would you still be interested in } \\
\text { sponsoring your staff to attend any of } \\
\text { these courses? } \\
\text { Yes (GO TO Q.103.3) } \\
\text { No (GO TO NEXT COURSE) }\end{array}$ & $\begin{array}{l}103.3 \\
\text { How many staff would you wish to } \\
\text { sponsor in the next one year for }<\text { name }> \\
\text { course? } \\
\text { (Insert Number) } \\
\text { GO TO NEXT COURSE } \\
\text { 99. Not Applicable }\end{array}$ \\
\hline CRS01 & $\begin{array}{l}\text { AIDS Orientation Workshop } \\
(\text { ACOW) }\end{array}$ & & & \\
\hline CRS02 & $\begin{array}{l}\text { Introduction to HIV/AIDS } \\
\text { Counseling }\end{array}$ & & & \\
\hline CRS03 & $\begin{array}{l}\text { HIV/AIDS Counseling Course } \\
\text { (Modular) }\end{array}$ & & & \\
\hline CRS04 & $\begin{array}{l}\text { HIV/AIDS Counseling Course } \\
\text { (Block) }\end{array}$ & & & \\
\hline CRS05 & $\begin{array}{l}\text { HIV/AIDS Counselor } \\
\text { Supervisors' Course }\end{array}$ & & & \\
\hline CRS06 & Counselor Refresher Course & & & \\
\hline CRS08 & $\begin{array}{l}\text { HIV/AIDS Community care Course } \\
\text { (TOT)- Regional }\end{array}$ & & & \\
\hline CRS011 & TOT Community Refresher co & & & \\
\hline CRS013 & Child Counseling Course & & & \\
\hline CRS014 & Peer Counseling Course (Youth) & & & \\
\hline CRS015 & Peer Counseling Course (Clients) & & & \\
\hline
\end{tabular}


(Note which rows are marked with “1” for Q. 103.2) 
[Instruction to interviewer: The following questions are to do with changes in fee structure for courses where an institution has expressed interest in sponsoring staff to attend - only applicable where Q. 103.2 is YES “ 1 ”]

104. I now want seek your opinion about changes in the fee structure for courses that you intend sponsor participants to attend. Assume that the income for your organization remains the same and that you have other potential sources for training your staff other than TASO. (Work across one row then go to next row)

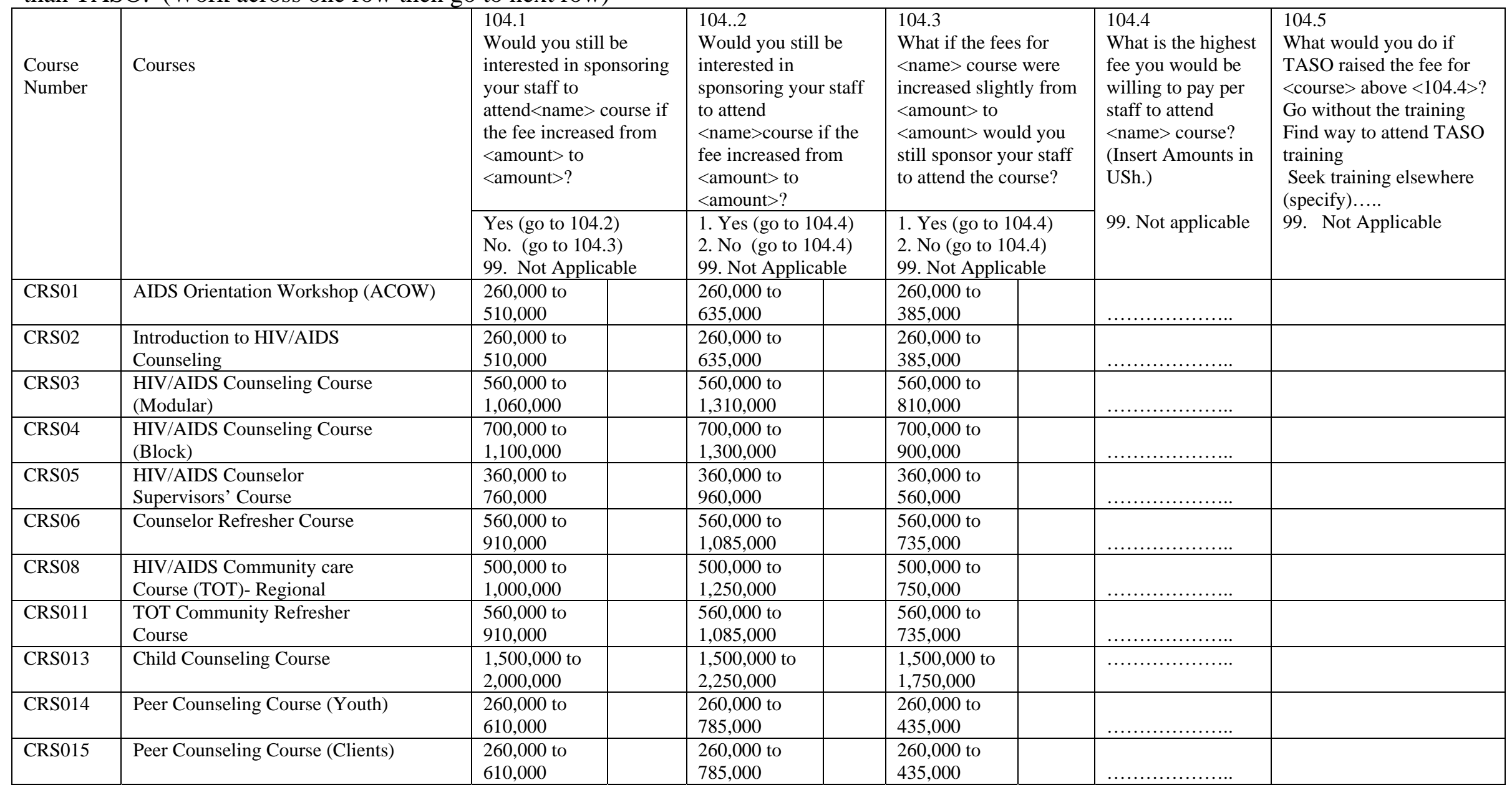

Thank you for your cooperation. 


\section{ANNEX 5: COURSE SPECIFIC RECOMMENDATIONS}

\section{CRSO1: AIDS CARE ORIENTATION WORKSHOP}

- Charge a fee of 410,000 USh. for all local participants. This will yield a small positive contribution margin for each student and increase the cost recovery percentage for this course from $45.5 \%$ to $71.8 \%$.

- A further consideration is the removal or reduction of participant per diems as course expenditures. This accounts for $82 \%$ of the variable cost per participant. If removed, the total variable cost of the course will reduce by 9.9 million USh.

- TASO may consider offering a dedicated one-week package for a flat rate of 13.5 million USh. per institution. As long as enrollment does not exceed 20 students, this package would generate positive net revenues for TASO.

\section{CRSO2: INTRODUCTION TO HIV COUNSELING}

- At the current class size of 20, charge a fee of 400,000 USh. for all local participants. This will increase the contribution margin by 140,000 USh. and the cost recovery levels will improve from $47 \%$ to $72 \%$.

- Other possibilities to be explored include collapsing this course from 10 days to 7 days. This would increase cost recovery to $69.6 \%$.

- The fee for international participants should be US $\$ 1,200$ considering the duration the course for the course. The charges would match with those of other courses.

\section{CRSO3: HIVIAIDS COUNSELING COURSE (MODULAR)}

- Although the willingness to pay data suggests an unwillingness to pay more than the current course fee of 560,000 USh, course participants are already paying a fee of 840,000 USh. While this yields a positive contribution margin, increasing enrollment cannot offset the large fixed costs associated with a 6-month course. Therefore TASO should continue charging the current revised fee as this improves cost recovery percentages from $42 \%$ to $64 \%$.

- TASO should consider whether or not the classroom component of the course could be shortened (a reduction from 25 to 20 days would increase cost recovery percentage from $42.3 \%$ to $51.7 \%)$.

\section{CRSO4: HIV/AIDS COUNSELING COURSE (BLOCK)}

- Since the class composition for this course included international participants, local participants should pay 1,100,000 USh. to cover variable costs. This will increase cost recovery from $32.8 \%$ to $51.5 \%$ a modest increase but as in CRS 03 there seems little willingness to accept higher fees.

- Reducing the class days from 15 to 10 could yield a small positive contribution margin, but due to high fixed costs, this would have minimal impact on the cost recovery percentage (increase to $40.0 \%$ ). 


\section{CRSO5: HIVIAIDS COUNSELOR SUPERVISOR'S COURSE}

- This course has unusually high fixed and variable costs due to large per diems for participants and trainers (70,000 USh.) and consultant fees that account for over $20 \%$ of the total variable costs. The need to maintain these high costs needs to be addressed. A fee of 500,000 USh. at $69.9 \%$ percentile for organizations and the same for individuals at $71.2 \%$ percentile are recommended. At the current class size the recommended fee will improve cost recovery percentages from $11 \%$ to $20 \%$ but the per participant contribution margin remains negative.

- To cut down on travel costs for the consultant who is sourced externally, TASO may consider rescheduling the course to be run immediately after course CRS 13 (child counseling) while at the same time working out a strategy to phase out the consultant in the long run.

\section{CRSO6: HIV/AIDS COUNSELOR REFRESHER COURSE}

- This course is currently breaking even and therefore, TASO may consider charging a maximum fee of 600,000 USh. to both institutional and non-institutional participants.

- In addition, because each participant adds more to revenues than to costs, the potential of increasing class size to 20 participants should be explored.

- If successful, these two changes are expected to yield a cost recovery percentage of $117 \%$, more than the total cost of the course. The excess revenue could be used to subsidize other courses.

\section{CRSO8: HIVIAIDS COMMUNITY CARE COURSE (TOT)}

- Since this course is regional targeting international participants, a fee of 1,000,000 USh. is recommended for local participants to cover variable costs. This will however reduce cost recovery percentage from $76 \%$ to $50 \%$. This estimate is based upon the assumption that half the participants are local and the other half international participants.

- In addition, attracting more international participants will improve financial sustainability as they currently pay more than it costs to provide the course. Though a target of 50\% international participants and 50\% local participants should be considered.

- An increase in class size, assuming the ratio of international to local participants does not drop below $50 \%$ will improve financial sustainability of this course.

- This course has unusually high fixed and variable costs due to large per diems for participants and trainers (80,000 USh. and 55,000 USh. respectively). Elimination of participant per diems should be considered.

- Shortening the course to 2 weeks would allow the course to generate positive net revenues that can be used to offset the costs of other TASO courses. 


\section{CRS11: REFRESHER COURSE FOR COMMUNITY TRAINERS}

- Currently the course is breaking even, however, a small fee increase to 600,000 USh. for local participants is recommended.

- In addition, because each participant adds more to revenues than to costs, the potential of increasing class size above its current level of 20 participants should be explored. TASO should create demand for this course/develop a marketing strategy targeting institutions

- If successful, these two changes are expected to yield a cost recovery of almost $50 \%$ more than the total cost of the course. The excess revenue could be used to subsidize other courses.

\section{CRS13: CHILD COUNSELING COURSE}

- There is very little scope for increasing the fees for this course. The local participants are paying 1,500,000 USh. which is quite high by local standards.

- This course has unusually high fixed and variable costs due to large per diems for participants and trainers (80,000 USh. for all). Elimination of participant per diems should be considered. Participant per diems account for over $50 \%$ of total course costs.

- The only way to cover the variable costs of this course is for TASO to continue charging international clients a fee of 4,080,000 USh. Currently the participants are $40 \%$ international and $60 \%$ local which yields a $78.8 \%$ cost recovery percentage.

- TASO should also consider building local capacity for this course (TOTS) to reduce costs on external consultants. Consultant payments account for $5.5 \%$ of total course costs.

\section{CRS14: YOUTH PEER COUNSELING COURSE}

- Even though institutions are reluctant to pay as much as individuals, it is recommended that a standard fee of 435,000 USh. be set for this course. This change by itself will not be sufficient to yield a positive contribution margin.

- In addition to a higher fee, if the course length could be reduced to one week, these modifications combined will yield a positive contribution margin and increase the cost recovery percentage from $27.2 \%$ to $78.5 \%$.

- TASO may also consider trying to increase the class size closer to the break-even point of 25 students.

\section{CRS15: CLIENT PEER COUNSELING COURSE}

- Similar to CRS 14, three changes are recommended:

o Increase the course fee to 310,000 USh.,

o Reduce the course length to one week, and

o Increase course size to 25 persons

- Taken together, these changes will yield a positive contribution margin and increase the cost recovery percentage from $27.2 \%$ to $62.7 \%$. 